\title{
PERTUMBUHAN DAN LAJU MORTALITAS LOBSTER BATU HIJAU (Panulirus homarus) DI PERAIRAN CILACAP JAWA TENGAH
}

\author{
Nurul Mukhlish Bakhtiar, Anhar Solichin, Suradi Wijaya Saputra ${ }^{1}$ \\ Program Studi Manajemen Sumberdaya Perairan, Jurusan Perikanan \\ Fakultas Perikanan dan Ilmu Kelautan, Universitas Diponegoro
}

\begin{abstract}
ABSTRAK
Lobster merupakan salah satu komoditas unggulan yang memiliki nilai ekonomis tinggi. Tingginya intensitas penangkapan yang tidak terkendali menyebabkan ukuran rata - rata lobster yang tertangkap semakin kecil dan nilai ekonomisnya semakin rendah. Oleh karena itu, penelitian ini dilaksanakan untuk memberikan beberapa informasi mengenai aspek biologi lobster. Tujuan dari penelitian ini antara lain untuk mengetahui pertumbuhan, laju mortalitas, dan pola rekrutmen lobster. Penelitian ini dilaksanakan pada Bulan September sampai Bulan Januari di Perairan Cilacap. Penelitian ini menggunakan metode deskriptif dengan teknik pengambilan data simple random sampling. Lobster yang didaratkan di TPI Menganti dan Sentolokawat diambil seluruh hasil tangkapan kemudian dilakukan identifikasi, pengukuran panjang, dan penimbangan berat. Data diambil setiap satu bulan sekali selama lima bulan. Data dianalisis ukuran pertama kali tertangkap, faktor kondisi, nisbah kelamin, hubungan panjang-berat, pendugaan parameter pertumbuhan, laju mortalitas, dan pola rekrutmen. Didapatkan hasil ukuran pertama kali tertangkap $\left(\mathrm{L}_{50 \%}=43,5 \mathrm{~mm}\right)$ kurang dari setengah panjang asimtotik $\left(1 / 2 \mathrm{~L}_{\infty}=55,5 \mathrm{~mm}\right)$. Hubungan panjang-berat lobster jantan yaitu $\mathrm{W}=0,00293 \mathrm{~L}^{2,71}$ dan lobster betina $\mathrm{W}$ $=0,00196 \mathrm{~L}^{2,83}$. Faktor kondisi pada lobster jantan $(1,02)$ dan betina $(1,01)$ mempunyai tingkat kemontokan yang sama. Nisbah kelamin yang didapatkan antara lobster jantan dibanding lobster betina yaitu 1,774 : 1. Hasil uji chi square antara jantan dan betina didapatkan berbeda nyata sehingga dapat dinyatakan tidak seimbang. Persamaan pertumbuhan Von Bertalanffy lobster jantan Lt $=110\left(1-\mathrm{e}^{-0,31(\mathrm{t}+0,37)}\right)$ dan lobster betina $\mathrm{Lt}=94,5\left(1-\mathrm{e}^{-}\right.$ $0,26(t+0,47)$, sehingga dapat dinyatakan pertumbuhan lobster jantan lebih cepat daripada lobster betina. Mortalitas total (Z) didapatkan sebesar 1,6 per tahun, mortalitas alaminya (M) sebesar 0,69 per tahun, mortalitas penangkapan (F) sebesar 0,91 per tahun. Tingkat eksploitasi (E) didapatkan sebesar 0,57 per tahun sehingga dapat dikategorikan termasuk dalam keadaan penangkapan berlebih. Pola penambahan baru lobster di Perairan Cilacap ini memiliki dua puncak yaitu pada bulan Juni dan Oktober. Berdasarkan hasil penelitian ini dapat disimpulkan bahwa penangkapan lobster $P$. homarus sudah dalam keadaan growth overfishing yang dikhawatirkan akan mengarah kepada recruitment overfishing.
\end{abstract}

Kata kunci: Panulirus homarus, hubungan panjang-berat, pertumbuhan, laju mortalitas, pola rekrutmen

\section{ABSTRACT}

Lobster is one of valuable comodity with higher price in the market. The high intensity of uncontrolled fishing causes the average size of the first caught is smaller than the economic size so the price is getting cheaper. Because of that, this research was held to give information about aspects of biology of spiny lobster. The purpose of this research is to know about growth, mortality, and recruitment pattern of spiny lobster. This research conducted in september to january. The method used in this research is descriptive method with simple random sampling technique. The catch of lobster that ashore in TPI Menganti and Sentolokawat identified and measured the length and weight. Data taken every month for five months. Data analyze of this research are the first size of caught, length-weight analyze, condition factor, growth parameter, mortality, and recruitment pattern. The result of first size of caught $\left(\mathrm{L}_{50 \%}=43,5 \mathrm{~mm}\right)$ is lower than the half of asymptotic length $(1 / 2$ $\left.\mathrm{L}_{\infty}=51,47\right)$. Length-weight relationship of male lobster is $\mathrm{W}=0,00293 \mathrm{~L}^{2,71}$ and female lobster is $\mathrm{W}=0,00196$ $\mathrm{L}^{2,83}$. The condition factor of male $(1,02)$ and female $(1,01)$ lobster has equal of plupmness. Sex ratio of male and female lobter has been tested use chi square and the result is unbalanced. Von Bertalanffy equation for male lobster is $\mathrm{Lt}=110\left(1-\mathrm{e}^{-0,31(\mathrm{t}+0,37)}\right)$ and female lobster is $\mathrm{Lt}=94,5\left(1-\mathrm{e}^{-0,26(t+0,47)}\right)$, so it can be stated the male lobster growing faster than female lobster. Total mortality $(\mathrm{Z})$ is obtained about 1,6 a year, natural mortality (M) is obtained about 0,69 a year, and mortality of catch $(\mathrm{F})$ is obtained about 0,91 a year. The level of exploitation $(\mathrm{E})$ is obtained about 0,57 a year, so it can be categorized in state of overfishing. The recruitment pattern of lobster on Cilacap waters has two peaks in June and October. Based on the results of this research it can be concluded that the fishing of lobster $P$. homarus on Cilacap waters in state of growth overfishing which it is feared will lead to recruitment overfishing.

Key words: Panulirus homarus, length-weight relationship, growth, mortality, recruitment pattern 


\section{Pendahuluan}

Perairan Indonesia yang beriklim tropis membawa konsekwensi suburnya terumbu karang yang merupakan habitat bagi udang karang (Panulirus spp.). Dari seluruh produksi udang laut, udang karang merupakan komoditas penting kedua setelah penaid. Oleh karena itu Udang karang merupakan komoditas perdagangan penting yang menarik untuk diusahakan penangkapannya (Dradjat, 2004).

Lobster merupakan salah satu komoditas unggulan yang memiliki nilai ekonomis tinggi. Hasil tangkapan lobster di Perairan Cilacap terdapat di dua TPI yaitu TPI Menganti dan TPI Sentolokawat. Lobster yang didaratkan di TPI Menganti hanya ada satu jenis yaitu $P$. homarus, sedangkan yang didaratkan di TPI Sentolokawat ada 6 jenis yaitu $P$. homarus, $P$. longipes longipes, $P$. penicilatus, $P$. polyphagus, $P$. versicolor, dan $P$. ornatus. Dari beberapa jenis lobster yang tertangkap, $P$. ornatus merupakan lobster yang paling mahal harganya. Satu kilogram lobster mutiara ( $P$. ornatus) berkisar antara Rp. 400.000,- hingga Rp. 1.000.000,tergantung dari ukuran lobster yang tertangkap. Ada juga lobster yang tiap hari selalu ada stoknya yaitu lobster batu hijau ( $P$. homarus). Lobster batu hijau merupakan lobster dengan harga menengah yakni berkisar antara Rp. 300.000,- hingga Rp. 600.000,-.

Lobster merupakan salah satu spesies ekonomis penting dan menjadi komoditas ekspor. Lobster merupakan salah satu target tangkapan utama nelayan, karena harga jual lobster yang sangat tinggi. Tingginya intensitas penangkapan dan banyaknya jumlah nelayan lobster menyebabkan kurang adanya pengelolaan terhadap ketersediaan stok lobster di perairan. Kurangnya pengendalian intensitas penangkapan juga menyebabkan ukuran rata - rata lobster yang tertangkap semakin kecil. Ukuran yang semakin kecil menyebabkan nilai ekonomis lobster semakin rendah. Kurangnya informasi mengenai musim puncak penangkapan lobster juga menyebabkan usaha penangkapan pada bulan - bulan tertentu mengalami penurunan produksi. Melihat kondisi tersebut maka diperlukan studi mengenai aspek biologi lobster terutama pada pertumbuhan, laju mortalitas, dan pola rekrutmen lobster tersebut. Penelitian ini menggunakan spesies $P$. homarus, karena spesies ini merupakan salah satu komoditas unggulan data hasil penelitian diharapkan dapat menjadi landasan untuk pengelolaan sumberdaya kerang selanjutnya.

Tujuan dari penelitian ini yaitu untuk mengetahui pertumbuhan lobster, laju mortalitas, dan pola rekrutmen lobster P. homarus di Perairan Cilacap. Penelitian ini dilaksanakan pada bulan September 2012 sampai Januari 2013 di Perairan Cilacap. Hasil penelitian ini diharapkan dapat menjadi tambahan informasi mengenai parameter pertumbuhan, laju mortalitas, dan pola rekrutmen lobster batu hijau ( $P$. homarus) yang selanjutnya diharapkan dapat menjadi pertimbangan bagi pengelolaan sumberdaya lobster di masa mendatang.

\section{Materi dan Metode Penelitian}

\section{A. Materi Penelitian}

Materi yang digunakan dalam penelitian ini adalah lobster batu hijau yang didaratkan di dua TPI, yaitu TPI Menganti dan TPI Sentolokawat. Alat yang digunakan dalam penelitian ini yaitu jangka sorong untuk mengukur panjang dengan ketelitian 0,1 milimeter. Timbangan elektrik digunakan untuk mengukur berat lobster ketelitian 0,1 gram. Kaca pembesar atau LUP digunakan untuk pengamatan lobster. Kertas folio dan ballpoint digunakan untuk menulis. Komputer digunakan sebagai alat untuk mengolah data. Kamera digital digunakan sebagai alat untuk mendokumentasikan kegiatan. Buku Identifikasi yang digunakan adalah buku identifikasi lobster menurut Chan (1998).

\section{B. Metode Penelitian}

Metode yang digunakan dalam penelitian ini adalah metode deskriptif. Tujuan dari metode deskriptif ini untuk memberikan suatu deskripsi atau gambaran secara sistematis, faktual dan akurat mengenai fakta-fakta, sifat serta hubungan antar fenomena yang diselidiki.

\section{Penentuan lokasi sampling}

Berdasarkan survei pendahuluan, bahwa hasil tangkapan hanya didaratkan di dua TPI, yaitu di TPI Menganti kisik dan TPI Sentolokawat. Setiap TPI yang mendaratkan hasil tangkapan lobster diambil seluruh tangkapan tersebut untuk dijadikan sampel. Pengambilan sampel dilakukan setiap satu bulan sekali selama lima bulan, yaitu mulai bulan September 2012 sampai bulan Januari 2013.

\section{Pengambilan sampel lapangan}

Teknik pengumpulan data menggunakan simple random sampling. Data yang dikumpulkan antara lain ukuran panjang $(\mathrm{mm})$ lobster, berat (gr) lobster, dan alat tangkap yang digunakan (jenis, ukuran mata jaring, dan jumlah alat tangkap). Sampel yang didapatkan akan diidentifikasi menggunakan buku referensi yang ditulis Chan (1998), yaitu dengan membedakan, warna dan bentuk tubuh, bentuk alat kelamin jantan dan betina, serta dapat dillihat berdasarkan bentuk pada tanduk terdepan, bentuk abdomen, dan bentuk telson. Panjang karapas diukur mulai dari ujung tanduk (dekat mata) hingga batas antara karapas dan abdomen menggunakan jangka sorong. Berat lobster diukur dengan menimbang menggunakan timbangan elektrik. Data alat tangkap yang digunakan didapatkan dengan wawancara langsung dengan nelayan. 


\section{Ukuran pertama kali tertangkap}

Analisis penangkapan lobster batu hijau (Panulirus homarus) dapat dilihat berdasarkan struktur ukuran dengan menghitung ukuran pertama kali tertangkap, ukuran rata-rata tertangkap, baik berdasarkan data panjang karapas maupun berat. Menurut Saputra (2009), ukuran panjang karapas pertama kali tertangkap Lc50\% diperoleh melalui plotting antara persentase frukuensi kumulatif ukuran ikan dengan ukuran ikan itu sendiri. Apabila dari titik potong antara kurva dengan titik 50\% yang ditarik vertikal memotong sumbu $\mathrm{x}$ (panjang), maka akan diperoleh ukuran rata-rata 50\% ikan yang tertangkap. Nilai tersebut akan menjelaskan bahwa 50\% ikan yang tertangkap kurang dari ukuran mesh size alat tersebut dan 50\% lainnya berukuran lebih besar dari ukuran tersebut.

\section{Analisa hubungan panjang-berat} persamaan:

Menurut Effendie (1997) analisis hubungan panjang berat, dihitung dengan menggunakan

Dimana:

$$
W=a L^{b}
$$

$\mathrm{W}=$ berat tubuh $($ gram $)$

$\mathrm{L}=$ panjang karapas $(\mathrm{mm})$

$\mathrm{a}=$ konstanta atau intersep

$\mathrm{b}=$ eksponen atau sudut tangensial

Persamaan ini dapat diselesaikan melalui transformasi linear logaritme dalam bentuk sebagai berikut :

$\log \mathrm{W}=\log \mathrm{a}+\mathrm{b} \log \mathrm{L}$

Dengan demikian persamaan ini dapat diselesaikan seperti menyelesaikan persamaan linier biasa.

Untuk mengetahui apakah terdapat perbedaan atau tidak dalam pertambahan panjang dan berat lobster jantan dan betina pada bulan yang sama, maka dilakukan analisis kovarian menurut petunjuk Steel dan Torrie (1980). Uji t nilai b terhadap 3 bertujuan untuk mengetahui apakah pertumbuhan lobster tergolong isometrik atau alometrik. Dengan hipotesis sebagai berikut:

$\mathrm{H}_{0}$ : Nilai $\mathrm{b}=3$, sehingga pertumbuhan bersifat isometrik

$\mathrm{H}_{1}$ : Nilai $\mathrm{b} \neq 3$, sehingga pertumbuhan bersifat allometrik

Jika $\mathrm{b}=3$, maka pertumbuhannya isometris, yaitu tingkat pertumbuhan panjang, lebar dan tinggi ikan adalah sama (Everhart dan Youngs, 1981). Jika tidak sama dengan 3, pertumbuhannya allometris, yaitu allometris positif apabila $\mathrm{b}>3$ dan allometris negatif apabila $\mathrm{b}<3$.

\section{Faktor Kondisi}

Perhitungan faktor kondisi (Ponderal Index) berdasarkan pada data panjang dan berat, menurut Effendie (1997) dapat dirumuskan sebagai berikut:

Dimana:

$$
K n=W / W^{\prime}
$$

Kn $\quad=$ Faktor Kondisi

$\mathrm{W} \quad=$ Berat rata-rata sesungguhnya

$\mathrm{W}^{\prime} \quad=$ Berat rata-rata perhitungan $\left(\mathrm{aL}^{\mathrm{b}}\right)$

Nilai faktor kondisi akan lebih penting dan lebih bermakna jika dibandingkan antar ukuran atau antar lokasi, karena jika terpaku hanya kepada satu nilai FK tidak banyak artinya, atau bahkan tidak ada (Saputra, 2009).

\section{Pendugaan parameter pertumbuhan}

Perhitungan persamaan pertumbuhan menggunakan metode ELEFAN I (electro length frequency analysis) yang terdapat dalam paket program FISAT II. L ${ }_{\infty}$ dapat diduga menggunakan rumus Pauly (1984) dengan rumus:

Dimana:

$$
\mathrm{L} \infty=\mathrm{Lmaks} / 0,95
$$

$\mathrm{L}_{\text {maks }}=$ panjang sampel tertinggi yang didapatkan

Dalam program ELEFAN I data yang digunakan akan menghasilkan palung dan puncak untuk menduga indeks yang sesuai $\left(\mathrm{R}_{\mathrm{n}}\right)$ dalam rumus:

Dimana:

$$
\mathrm{R}_{\mathrm{n}}=10^{\mathrm{ESP} / \mathrm{ASP}} / 10
$$

ASP = Available Sum Peak

$\mathrm{ESP}=$ Explained Sum Peak

Nilai $\mathrm{R}_{\mathrm{n}}$ (indeks kesesuaian) digunakan untuk menduga nilai $\mathrm{K}$ (koefisien pertumbuhan) dalam bentuk skala $0,1-10,0$. Kemudian untuk mendapatkan pendugaan nilai $\mathrm{K}$ yang terbaik menggunakan output dari Response surface analysis.

Penentuan nilai $t_{0}$ menurut Saputra (2009) menggunakan rumus empiris Pauly dengan menggunakan hubungan regresi berganda antara umur teoritis saat panjang ikan nol $\left(\mathrm{t}_{0}\right)$ dengan panjang infinity $\left(\mathrm{L}_{\infty}\right)$ dan $\mathrm{K}$, yaitu sebagai berikut: 
Dimana:

$$
\log -\mathrm{t} 0=-0,3952-0,2752 \log \mathrm{L} \infty-1,038 \log \mathrm{K}
$$

$\mathrm{L}_{\infty} \quad=$ Panjang infiniti $(\mathrm{cm})$

$\mathrm{K} \quad=$ Koefisien pertumbuhan Von Bertalanffy

Laju pertumbuhan diduga dengan model Von Bertalanffy (Gulland, 1983) dengan rumus sebagai berikut:

Dimana :

$$
L t=L \infty\left(1-e^{-k(t-t 0)}\right)
$$

$\mathrm{L}_{\mathrm{t}} \quad$ = Panjang ikan pada umur $\mathrm{t}(\mathrm{cm})$

$\mathrm{L}_{\infty} \quad=$ Panjang infiniti $(\mathrm{cm})$

$\mathrm{t}_{0} \quad=$ Umur teoritis ikan pada panjang 0

$\mathrm{K}=$ Koefisien pertumbuhan Von Bertalanffy

\section{Pendugaan laju mortalitas}

Penghitungan nilai Z (mortalitas total) didapatkan dengan menggunakan metode kurva tangkapan yang dikonversi ke panjang, dalam paket program FISAT II. Rumus penghitungan hilai Z adalah sebagai berikut:

Dimana:

$$
\ln (\mathrm{Ni} / \Delta \mathrm{ti})=\mathrm{a}+\mathrm{b} \cdot \mathrm{ti}
$$

$\mathrm{Ni}=$ jumlah ikan pada panjang kelas $\mathrm{i}$

$\Delta \mathrm{t}_{\mathrm{i}}=$ Waktu yang dibutuhkan ikan untuk tumbuh pada panjang kelas $\mathrm{i}$

$\mathrm{t}_{\mathrm{i}} \quad$ = umur pada nilai tengah panjang kelas $\mathrm{i}$

M (mortalitas alami) dihitung berdasarkan rumus empiris Pauly (1984) dengan memasukkan parameter K per tahun, $\mathrm{L}_{\infty}(\mathrm{mm})$, dan $\mathrm{T}$ (rata-rata suhu permukaan air tahunan dalam derajat Celcius). Rumus empiris Pauly adalah sebagai berikut:

Dimana:

$$
\log M=-0,0066-0,279 \log \operatorname{Lo}+0,6453 \log K+0,4634 \log T
$$

$\mathrm{M}=$ Koefisien mortalitas alami

$\mathrm{L}_{\infty}=$ Panjang infiniti $(\mathrm{cm})$

$\mathrm{K}=$ Koefisien pertumbuhan Von Bertalanffy

$\mathrm{T}=$ Suhu rata - rata perairan Indonesia kurang lebih $28^{\circ} \mathrm{C}$ (Subani 1977 dan Data SPL Bulan September 2012 hingga Januari 2013)

Mortalitas penangkapan $(\mathrm{F})$ dapat dihitung dengan mengurangkan mortalitas total $(\mathrm{Z})$ terhadap mortalitas alami (M), dengan rumus di bawah ini:

$$
Z=F+M, \text { menjadi: } F=Z-M
$$

Dimana:

$\mathrm{Z}=$ Koefisien mortalitas total

$\mathrm{F}=$ Koefisien mortalitas penangkapan

$\mathbf{M}=$ Koefisien mortalitas alami

Berdasarkan nilai dugaan laju mortalitas akibat penangkapan (F) dibagi dengan laju mortalitas total (Z), maka laju eksploitasi (E) dapat diduga dengan rumus berikut:

Dimana:

$$
E=F / Z
$$

$\mathrm{E}=$ Laju eksploitasi atau bagian dari mortalitas yang disebabkan oleh penangkapan

$\mathrm{F}=$ Mortalitas penangkapan

$\mathrm{Z}=$ Mortalitas total

Jika nilai $\mathrm{E}=0,5$ menunjukkan bahwa nilai tersebut optimum $\left(\mathrm{E}_{\mathrm{opt}}\right)$, hal ini didasarkan pada asumsi bahwa hasil berimbang adalah optimum bila F=M (Gulland 1971 dalam Pauly 1983).

\section{Pola rekrutmen}

Pola rekrutmen didapatkan menggunakan program FISAT II pada sub program recruitmen pattern. Program tersebut akan menampilkan persentase rekruitmen selama penelitian. Hasil dari pendugaan berupa histogram dengan memasukkan file dengan format .lfq (grouped frequencies) yang akan digunakan kemudian memasukkan nilai $\mathrm{L}_{\infty}, \mathrm{K}$, dan $\mathrm{t}_{\mathrm{o}}$ yang telah dihitung sebelumnya.

\section{Hasil dan Pembahasan}

\section{Deskripsi lokasi}

Kabupaten Cilacap merupakan daerah terluas di Jawa Tengah, dengan batas wilayah sebelah selatan Samudra Hindia, sebelah utara berbatasan dengan Kabupaten Banyumas dan Kabupaten Brebes, sebelah timur berbatasan dengan Kabupaten Kebumen dan sebelah barat berbatasan dengan Kabupaten Ciamis dan Kota Banjar Propinsi Jawa Barat. Terletak diantara 108 4'30" - 109 $30^{\prime} 30^{\prime \prime}$ garis Bujur Timur dan $7^{0} 30^{\prime}-7^{0} 45^{\prime} 20^{\prime \prime}$ garis Lintang Selatan, mempunyai luas wilayah 225.360,840 Ha. Jarak terjauh dari barat ke timur $152 \mathrm{~km}$ dari Kecamatan Dayeuhluhur ke Kecamatan Nusawungu dan dari utara ke selatan sepanjang $35 \mathrm{~km}$ yaitu dari Kecamatan Cilacap Selatan ke Kecamatan Sampang (http://www.cilacapkab.go.id). 


\section{Distribusi panjang}

Lobster yang sudah teridentifikasi, kemudian dilakukan pengukuran panjang dan berat. Panjang yang didapatkan kemudian dianalisa dengan progression analysis untuk mengetahui kohort pada masing - masing histogram setiap bulan. Distribusi panjang karapas P. homarus dapat dilihat pada Gambar 1.
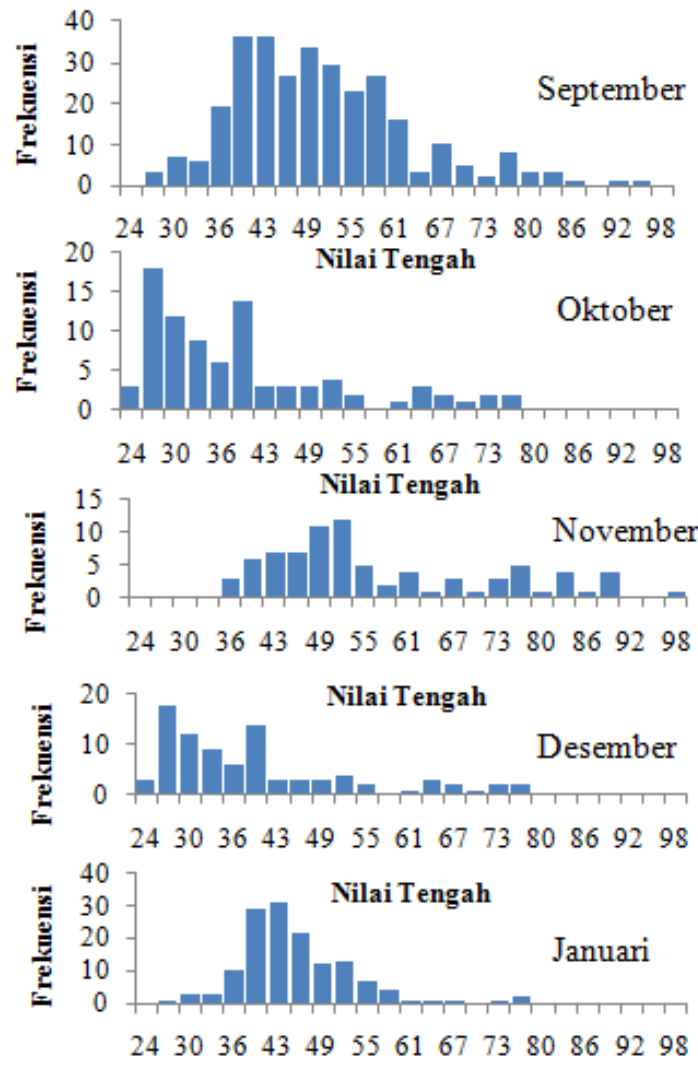

Nilai Tengah

Gambar 1. Distribusi Panjang Pada Bulan September Sampai Januari

\section{Ukuran pertama kali tertangkap}

Berdasarkan analisa ukuran pertama kali tertangkap bahwa panjang asimtotik $\left(\mathrm{L}_{\infty}\right)$ Panulirus homarus $111 \mathrm{~mm}$. Setengah panjang asimtotik $\left(1 / 2 \mathrm{~L}_{\infty}\right)$ didapatkan $55,5 \mathrm{~mm}$. Ukuran panjang karapas pertama kali tertangkap $\left(\mathrm{L}_{50 \%}\right)$ yaitu $43,5 \mathrm{~mm}$, plotting ukuran karapas pertama kali tertangkap dapat dilhat pada Gambar 2.

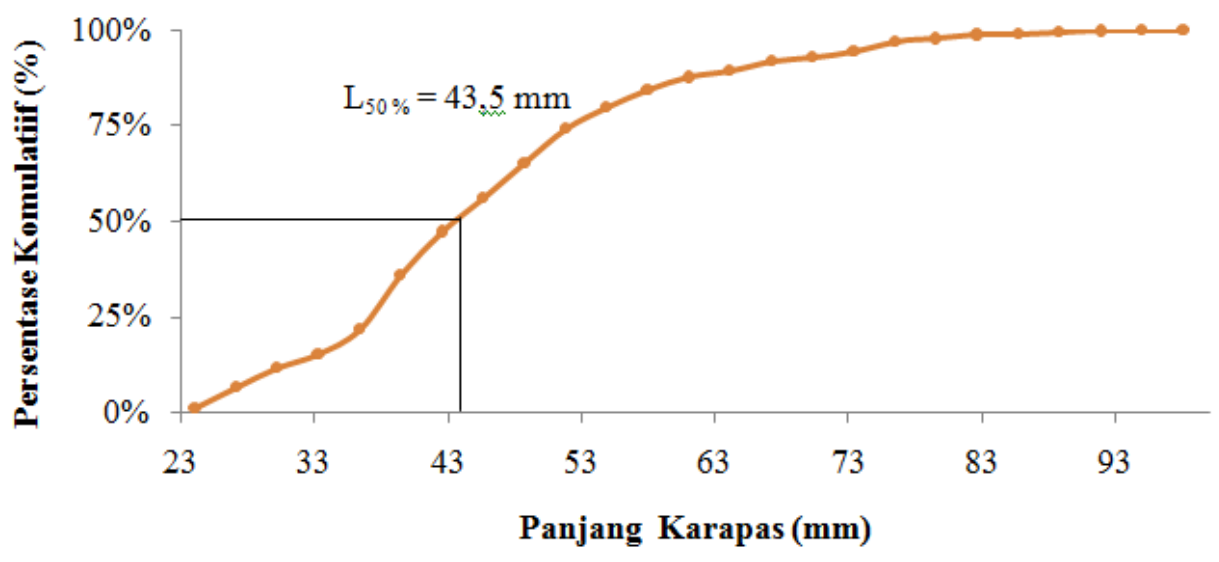

Gambar 2. Ukuran Pertama Kali Tertangkap Panulirus homarus.

\section{Hubungan panjang berat}

Pendugaan hubungan panjang berat didasarkan pada sampel yang diperoleh dari hasil tangkapan pada bulan September 2012 hingga Januari 2013. Data hasil perhitungan panjang berat dan faktor kondisi dari penelitian ini tersaji dalam Tabel 1. 
http://ejournal-sl.undip.ac.id/index.php/maquares

Tabel 1. Hasil Analisa Panjang Berat dan Faktor Kondisi Panulirus homarus

\begin{tabular}{lccc}
\hline \multirow{2}{*}{ Parameter } & \multicolumn{3}{c}{ Data dan Hasil Perhitungan } \\
\cline { 2 - 4 } & Jantan dan Betina & Jantan & Betina \\
\hline $\mathrm{n}$ & 699 & 447 & 252 \\
$\mathrm{~W}=\mathrm{aL}^{\mathrm{b}}$ & $0,00249 \mathrm{~L}^{2,76}$ & $0,00293 \mathrm{~L}^{2,71}$ & $0,00196 \mathrm{~L}^{2,83}$ \\
Pola pertumbuhan & Allometrik (-) & Allometrik (-) & Allometrik (-) \\
Faktor Kondisi & & 1,02 & 1,01 \\
Perbandingan nisbah kelamin & & 1,774 & $\mathbf{1}$ \\
\hline
\end{tabular}

Perbandingan nisbah kelamin P. homarus, antara jantan dengan betina yaitu 1,774: 1. Faktor kondisi yang didapatkan untuk jantan yaitu 1,02 dan betina 1,01 artinya antara jantan dan betina kemontokannya sama. Nilai b yang didapatkan untuk jantan dan betina sebesar 2,76 dengan nilai b jantan sebesar 2,71 dan betina 2,83. Uji t dilakukan pada jantan, betina, dan gabungan didapatkan hasil bahwa $b \neq 3$, sehingga dapat disimpulkan termasuk dalam kategori allometrik negatif. Persamaan hubungan panjang-berat pada lobster gabungan (jantan dan betina) yaitu $\mathrm{W}=0,00249 \mathrm{~L}^{2,76}$, pada lobster jantan yaitu $\mathrm{W}=0,00293 \mathrm{~L}^{2,71}$ dan lobster betina $\mathrm{W}=0,00196$ $\mathrm{L}^{2,83}$. Kisaran ukuran panjang karapas lobster jantan yaitu 23-97 mm, sedangkan untuk panjang karapas lobster betina kisaran ukurannya antara 26-90 mm. Grafik hubungan panjang karapas dan berat tersaji pada Gambar 3.

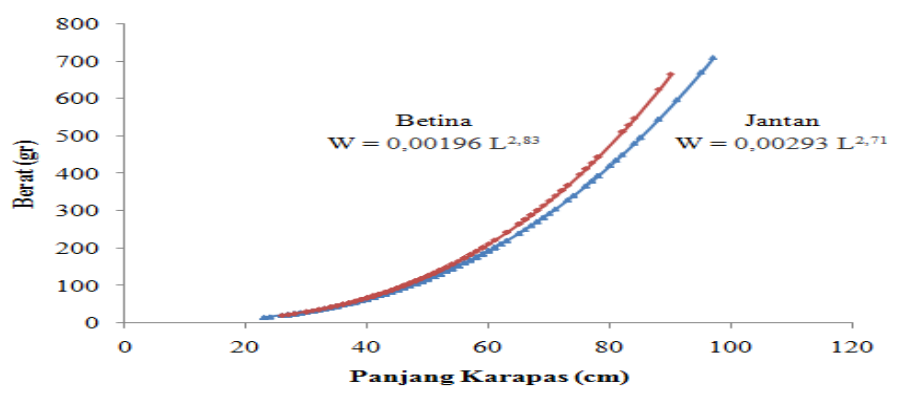

Gambar 3. Hubungan Panjang Karapas (mm) dan W (gr) P. homarus di Perairan Cilacap

\section{Pendugaan parameter pertumbuhan}

Pendugaan parameter pertumbuhan pada persamaan Von Bertalanffy, dengan menggunakan alat bantu software FiSAT II dan rumus empiris Pauly (1984) untuk menduga $t_{0}$. Hasil penghitungan pendugaan parameter pertumbuhan tersaji dalam Tabel 2.

Tabel 2. Hasil Penghitungan Pendugaan Parameter Pertumbuhan.

\begin{tabular}{lccc}
\multicolumn{1}{c}{ Parameter } & Jantan & Betina & Keterangan \\
\hline $\mathrm{L}_{\max }(\mathrm{mm})$ & 97 & 90 & Pengamatan \\
$\mathrm{L}_{\infty}(\mathrm{mm})$ & 110,00 & 95,62 & ELEFAN I dalam FiSAT II \\
$\mathrm{K}$ (per tahun) & 0,31 & 0,26 & ELEFAN I dalam FiSAT II \\
$\mathrm{t}_{0}$ & $-0,37$ & $-0,47$ & Rumus Pauly (1984) \\
$\mathrm{L}_{\mathrm{t}}$ & $\mathrm{L}_{\mathrm{t}}=110\left(1-\mathrm{e}^{-}\right.$ & $\mathrm{L}_{\mathrm{t}}=95,62\left(1-\mathrm{e}^{-}\right.$ & Model pertumbuhan Von \\
& $0,31(\mathrm{t}+0,37)$ & $0,26(\mathrm{t}+0,47)$ & Bertalanffy \\
\hline
\end{tabular}

Hasil di atas dapat dilihat bahwa $\mathrm{L}_{\max }$ atau panjang maksimal pada saat pengamatan didapatkan hasil lobster jantan yaitu $97 \mathrm{~mm}$ dan betina $90 \mathrm{~mm}$. $\mathrm{L}_{\infty}$ didapatkan dengan cara dihitung menggunakan ELEFAN I dalam softwae FiSAT II diperoleh $\mathrm{L}_{\infty}$ jantan $110 \mathrm{~mm}$, dan $\mathrm{L}_{\infty}$ betina 95,62 $\mathrm{mm}$. Nilai $\mathrm{K}$ diperoleh untuk lobster jantan 0,31 dan nilai $\mathrm{K}$ lobster betina 0,26. Nilai $\mathrm{t}_{0}$ jantan sebesar -0,37 dan betina sebesar -0,47. Persamaan Von Bertalanffy (VGBE) untuk lobster jantan yaitu $\mathrm{L}_{\mathrm{t}}=110\left(1-\mathrm{e}^{-0,31(\mathrm{t}+0,37)}\right)$, dan betina yaitu $\mathrm{L}_{\mathrm{t}}=95,62\left(1-\mathrm{e}^{-}\right.$ $0,26(t+0,47)$.

Berdasarkan tabel di atas terlihat bahwa pertambahan panjang lobster jantan $(\mathrm{K}=0,31)$ lebih cepat dibandingkan lobster betina $(\mathrm{K}=0,26)$. Lobster jantan memiliki ukuran lebih panjang dibandingan dengan lobster betina. Tabel di atas juga menggambarkan bahwa untuk mencapai ukuran maksimum dibutuhkan waktu lebih dari 10 tahun. Berdasarkan kunci pertumbuhan lobster tersebut dapat dibuat suatu kurva pertumbuhan sebagaimana disajikan pada Gambar 4.

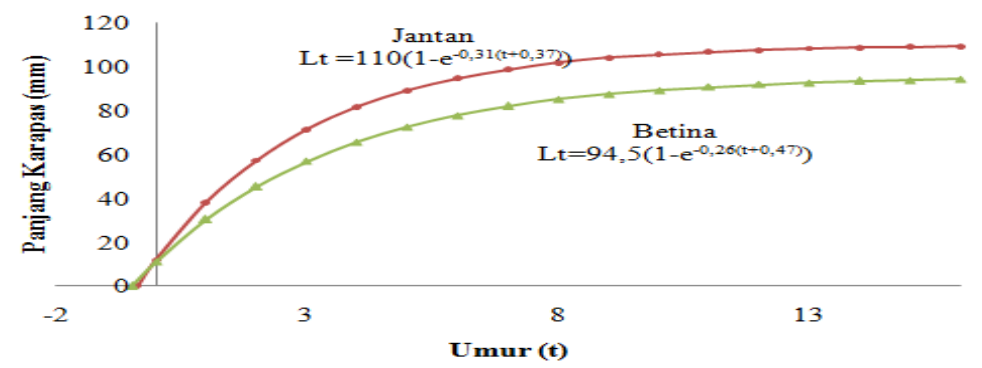

Gambar 4. Kurva Hubungan Antara Umur dengan Panjang Karapas P. homarus 


\section{Laju mortalitas}

Laju mortalitas pada penelitian ini hasilnya disajikan pada Tabel 3.

Tabel 3. Laju Mortalitas Panulirus homarus

\begin{tabular}{ccc}
\hline Parameter & Nilai & Keterangan \\
\hline $\mathrm{Z}$ & 1,6 & Menggunakan kurva berdasarkan konversi panjang \\
$\mathrm{M}$ & 0,69 & dalam FISAT II \\
$\mathrm{F}$ & 0,91 & Menggunakan rumus Pauly (1984) \\
$\mathrm{E}$ & 0,57 & $\mathrm{~F}=\mathrm{Z}-\mathrm{M}$ \\
$\mathrm{E}=\mathrm{F} / \mathrm{Z}$
\end{tabular}

Hasil nilai Z (mortalitas total) yang didapatkan sebesar 1,6 per tahun, mortalitas alami (M) sebesar 0,69 per tahun, Nilai F sebesar 0,91 per tahun. Hasil tersebut menggambarkan bahwa mortalitas penangkapan (F) lebih besar dibandingkan dengan mortalitas alami (M). Nilai E (laju eksploitasi) didapatkan dari hasil penghitungan $\mathrm{E}=\mathrm{F} / \mathrm{Z}$, dari rumus tersebut didapatkan nilai $\mathrm{E}$ sebesar 0,57 per tahun.

\section{Pola rekrutmen}

Pola rekrutmen didapatkan dengan memasukkan nilai $\mathrm{L}_{\infty}, \mathrm{K}$, dan $\mathrm{t}_{0}$, kemudian dihitung menggunakan software FiSAT II. Hasil penghitungan persentase dari pola rekrutmen dapat dilihat pada Tabel 4.

Tabel 4. Persentase Bulanan Penambahan Baru Panulirus homarus

\begin{tabular}{cc}
\hline Bulan & Persentase Rekrutmen (\%) \\
\hline Januari & 5,78 \\
Februari & 3,74 \\
Maret & 13,92 \\
April & 12,13 \\
Mei & 12,01 \\
Juni & 17,32 \\
Juli & 10,81 \\
Agustus & 9,64 \\
September & 3,13 \\
Oktober & 8,07 \\
November & 3,45 \\
Desember & 0 \\
\hline
\end{tabular}

Berdasarkan tabel 6 di atas, prosentase tertinggi didapatkan pada bulan Juni yaitu sebesar 17,32\%. Prosentase kedua dan ketiga berada pada bulan Maret dan April dengan prosentase masing - masing sebesar $13,92 \%$ dan $12,13 \%$. Tabel tersebut dapat disajikan dalam bentuk histogram pada Gambar 5

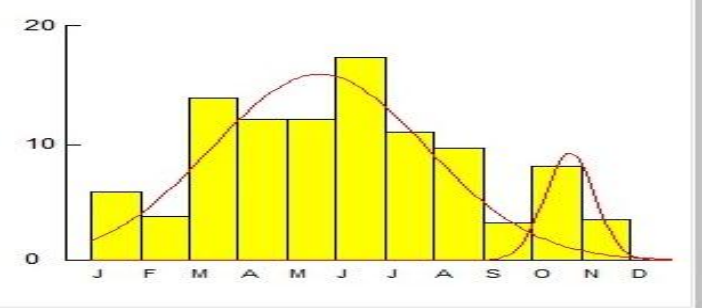

Gambar 5. Pola Rekrutmen Panulirus homarus

Hasil yang didapatkan menunjukkan bahwa rekrutmen terjadi hampir setiap bulan, hanya bulan Desember saja yang tidak ada rekrutmen. Pendugaaan puncak rekrutmen P. homarus berkisar pada bulan Juni dan Oktober.

\section{Struktur ukuran}

Lobster yang didapatkan di perairan Cilacap pada penelitian ini sebanyak 699 ekor dengan jumlah lobster jantan sebanyak 447 ekor dan jumlah lobster betina 252 ekor. Ukuran lobster terkecil yang didapatkan yaitu 23 mm (panjang karapas) dan ukuran terpanjang 97 mm (panjang karapas). Keseluruhan sampel yang diambil setiap bulan didapatkan modus yaitu $41 \mathrm{~mm}$ dengan hasil tangkapan sebanyak 35 ekor. Pada ukuran di bawah $41 \mathrm{~mm}$ frekuensinya sedikit karena pada ukuran tersebut kemungkinan belum masuk ke daerah penangkapan. Ukuran yang lebih besar dari $40 \mathrm{~mm}$ semakin lama semakin menurun, karena persentase tertangkap lebih besar dan juga kemungkinan adanya pengaruh mortalitas alami dimana lobster yang sudah tua akan mati.

Hasil dari pendugaan kelompok umur didapatkan di setiap pengambilan sampel terdapat 5 kelompok umur pada bulan September sampai Desember, namun bulan Januari hanya terdapat 4 kelompok umur. Populasi terbanyak pada bulan September yaitu berjumlah 138 ekor dengan ukuran rata- rata panjang karapas 41,92 mm. Bulan Oktober pada ukuran rata - rata panjang karapas $28 \mathrm{~mm}$ memiliki jumlah populasi terbanyak yaitu 38 ekor. Bulan November ukuran rata - rata panjang karapas 50,9 mm memiliki populasi terbanyak yaitu 28 ekor. Populasi terbanyak pada bulan Desember yaitu 35 ekor dengan ukuran rata - rata panjang karapas $28,1 \mathrm{~mm}$. Bulan Januari hanya terdapat 4 kelompok, pada ukuran rata - rata panjang karapas 42,93 mm memiliki jumlah populasi terbanyak yaitu 109 ekor. Berdasarkan perhitungan kelompok umur dan jumlah populasi yang 
didapatkan, terdapat perbedaan ukuran panjang karapas yang memiliki populasi terbanyak pada tiap bulannya. Perbedaan tersebut kemungkinan dikarenakan perbedaan lokasi penangkapan dan lobster belum atau sudah memasuki daerah penangkapan.

Hasil perhitungan kelompok umur pada bulan September sampai Januari, lobster diperkirakan berumur 0,5 tahun sampai 2,5 tahun. Masing - masing kelompok umur memiliki rentang 0,5 tahun. Ukuran ekonomis lobster untuk kategori layak konsumsi yaitu berada di atas $100 \mathrm{~g}$, berdasarkan perhitungan panjang - berat didapatkan pada ukuran $47 \mathrm{~mm}$ lobster bisa masuk dalam kategori konsumsi (A1). Berat $100 \mathrm{~g}$ sudah masuk kategori A1 dan pada standar berat tersebut sudah termasuk ukuran layak konsumsi dengan harga Rp. 300.000,- I $\mathrm{Kg}$. Ukuran panjang karapas lobster $47 \mathrm{~mm}$ kemudian dilakukan perhitungan umur dengan rumus Von Bertalanffy, hasil perhitungan yaitu pada ukuran $47 \mathrm{~mm}$ memiliki umur sekitar 1,06 tahun. Dapat disimpulkan bahwa lobster dapat mencapai ukuran ekonomis pada umur lebih dari 1 tahun. Ukuran yang kurang ekonomis sangat merugikan nelayan karena nila jual lobster yang rendah dan dari sisi pengelolaan banyaknya ukuran lobster yang masih kecil apabila tertangkap dapat berpotensi terhadap growth overfishing. Lobster yang belum sempat mencapai ukuran dewasa atau lebih dari $1 / 2 \mathrm{~L}_{\infty}$ apabila tertangkap, lobster tersebut tidak dapat melakukan reproduksi sehingga dikhawatirkan jumlahnya akan terus menurun. Ukuran pertama kali tertangkap yaitu 43,5 $\mathrm{mm}$ (panjang karapas). Ukuran tersebut belum layak tertangkap karena belum memasuki ukuran ekonomis dengan berat rata - rata sekitar kurang dari $100 \mathrm{~g}$. Ukuran yang layak konsumsi akan menguntungkan nelayan karena pendapatan mereka pun semakin tinggi dan usaha penangkapan yang dilakukan sepadan dengan biaya operasional. Nelayan di Cilacap rata - rata menggunakan alat tangkap gillnet, walaupun ada juga yang melakukan penangkapan dengan menyelam. Mesh size yang digunakan untuk menangkap lobster yaitu 3 inchi (1 inchi $=2,54 \mathrm{~cm}$ ) dengan selektifitas 1,71 .

Ukuran pertama kali tertangkap $\left(\mathrm{L}_{\mathrm{c} 50 \%}\right)$ yang didapatkan sebesar 43,5 mm lebih kecil daripada ukuran setengah panjang asimptotik $\left(1 / 2 \mathrm{~L}_{\infty}\right)$ yang didapatkan yaitu 55,5 mm. Berdasarkan ukuran modus $(41 \mathrm{~mm})$ dan $\mathrm{L}_{\mathrm{c} 50 \%}$ tersebut maka ukuran lobster yang tertangkap di Perairan Cilacap termasuk dalam kategori masih kecil. Dari hal tersebut dapat ditarik kesimpulan bahwa dari sisi peluang reproduksi lobster tidak terjamin, dan dari sisi pemanfaatannya termasuk dalam kategori penangkapan berlebih (growth overfshing) karena didominasi oleh lobster berukuran kecil. Kondisi ini juga dapat mengarah pada recruitment overfishing, karena kesempatan bagi lobster untuk berkembang biak semakin kecil. Penelitian yang dilakukan oleh Saputra (2008) di Perairan Kebumen juga didapatkan hal serupa, yakni $\mathrm{L}_{\mathrm{c} 50 \%}$ didapatkan sebesar 44,5 mm sedangkan $1 / 2$ L $\infty$ yang didapatkan 47,6 mm sehingga ukuran yang tertangkap lebih kecil dari ukuran ideal.

Menurut Saputra et al. (2008), ukuran rata-rata tertangkap atau ukuran pertama kali tertangkap idealnya tidak lebih kecil dari setengah panjang infiniti $\left(\mathrm{L}_{\infty}\right)$-nya. Hal ini berarti, dari sisi peluang reproduksi masih terjamin dan dari sisi pemanfaatannya menunjukkan bahwa eksploitasi masih belum berlebih.

\section{Analisa panjang berat}

Nilai b menggambarkan pola pertumbuhan pada lobster $P$. homarus nilai b yang didapatkan sebesar 2,758. Dengan menggunakan uji t terhadap $b$, ditarik kesimpulan bahwa $b \neq 3$ karena $t$ hitung $\geq t$ tabel. Nilai $b<$ 3 tersebut dapat dinyatakan bahwa pola pertumbuhan lobster $P$. homarus bersifat Allometrik negatif, dimana pertambahan panjang lebih cepat daripada pertambahan beratnya. Effendi (1987) mengatakan, nilai yang lebih besar atau lebih kecil dari 3 pertumbuhan ikan dikatakan allometrik. Jika nilai $b<3$, maka pertambahan panjang lobster tersebut tidak seimbang dengan pertambahan beratnya. Pertambahan panjangnya lebih cepat dari pada pertambahan beratnya.

Faktor kondisi yang didapatkan pada lobster jantan yaitu sebesar 1,02 dan betina 1,01. Berdasarkan nilai tersebut dapat dinyatakan bahwa lobster jantan dan betina mempunyai tingkat kemontokan yang sama. Nisbah kelamin yang didapatkan antara lobster jantan dibanding lobster betina yaitu 1,774: 1. Hasil uji chi square antara jantan dan betina didapatkan berbeda nyata sehingga dapat dinyatakan tidak seimbang antara jumlah jantan dibandingkan jumlah betina. Effendi (1997) menyatakan keseimbangan perbandingan antara individu jantan dan betina kemungkinan terjadinya pembuahan sel telur oleh spermatozoa semakin besar. Variasi nisbah kelamin tejadi karena tiga faktor yaitu perbedaan tingkah laku seks, kondisi lingkungan dan lokasi penangkapan. Pertumbuhan lobster

Hasil pendugaan parameter pertumbuhan $P$. homarus, didapatkan nilai $\mathrm{K}$ lobster jantan sebesar 0,31 dan nilai K betina sebesar 0,26. Persamaan pertumbuhan Von Bertalanffy lobster jantan Lt $=110\left(1-\mathrm{e}^{-0,31(t+0,37)}\right)$ dan lobster betina $\mathrm{Lt}=94,5\left(1-\mathrm{e}^{-0,26(t+0,47)}\right)$. Penelitian yang pernah dilakukan oleh Sanders dan Bouhlel (1984) dalam Jayakody (1993) di Yaman didapatkan nilai K lobster jantan $(\mathrm{K}=0,46)$ lebih besar dari betina $(\mathrm{K}=0,44)$. Di India $P$. homarus yang diteliti oleh Mohammed dan George (1968) dalam Jayakody (1993) didapatkan nilai K lobster jantan sebesar 0,72 dan betina 0,62, Jayakody (1993) melakukan penelitian mengenai $P$. homarus di Sri Langka mendapatkan nilai $\mathrm{K}$ lobster jantan sebesar 0,41 lebih besar dari betina yang memiliki nilai K sebesar 0,39. Dari hasil - hasil penelitian tersebut terlihat bahwa nilai K umumnya lebih besar dari penelitian ini.

Hasil penelitian P. homarus yang dilakukan oleh Mahasin (2003) di Perairan D. I. Yogyakarta, didapatkan panjang total asimtotiknya $13,8 \mathrm{~cm}$ dengan nilai $\mathrm{K}$ sebesar 0,36 per tahun. Penelitian mengenai $P$. homarus juga dilakukan oleh Dradjat (2004) di Perairan Kebumen, mendapatkan hasil panjang asimtotiknya $10,7 \mathrm{~cm}$ dengan nilai K sebesar 0,6 per tahun. Di daerah pantai Pangandaran juga pernah dilakukan penelitian 
mengenai $P$. homarus oleh Suman et al. (1994), dari penelitian tersebut didapatkan hasil panjang total asimtotiknya sebesar 110,5 mm dengan nilai K sebesar 0,75 per tahun. Sedangkan Subani (1983), juga pernah melakukan penelitian mengenai $P$. homarus di Selat Bali dan didapatkan hasil panjang asimtotiknya sebesar $30,51 \mathrm{~cm}$ (TL) dengan nilai K sebesar 1,03. Berdasarkan uraian di atas terlihat untuk lobster di Perairan Cilacap dan Perairan Yogyakarta memiliki nilai K yang relatif sama, tetapi lebih kecil dibanding dengan nilai $\mathrm{K}$ dari Perairan Kebumen, Pangandaran, dan Bali.

Namun berbeda pada penelitian yang dilakukan oleh Smale (1978) dalam Arellano (1989) di Durban, Afrika Selatan didapatkan nilai K lobster jantan sebesar 0,18 dan betina 0,34 , sehingga pertumbuhan lobster betina di Durban lebih cepat daripada lobster jantan. Terlihat bahwa untuk lobster jantan memiliki nilai K lebih kecil dari lobster di Perairan Cilacap. Perbedaan nilai pertumbuhan ini kemungkinan disebabkan oleh perbedaan ukuran sampel yang dianalisis, periode pengambilan sampel, kelimpahan makanan dan kondisi lingkungan. Menurut Froese et al.(2000), nilai K > 0,3 per tahun termasuk dalam kategori yang tinggi.

Menurut Morgan (1980) bahwa pertumbuhan dipengaruhi oleh beberapa faktor yaitu makanan, suhu, dan densitas. Menurut Suman et al. (1994), adanya perbedaan pertumbuhan udang karang dari berbagai perairan diduga disebabkan oleh perbedaan kisaran ukuran udang yang dianalisis, kelimpahan makanan, dan kondisi perairan serta metode analisis yang digunakan. Sementara menurut Tiews et al. (1970) dalam Sudrajad dan Nugroho (1983) berpendapat bahwa perbedaan kecepatan pertumbuhan spesies yang sama pada perairan yang berbeda antara lain disebabkan oleh kondisi lingkungan. Apabila dikaitkan dengan habitat lobster yang hidup di perairan tropis, maka pada umumnya udang di perairan tropis mempunyai nilai $\mathrm{K}$ lebih tinggi dibandingkan dengan perairan yang dingin. Nilai K juga terkait dengan metabolik ikan atau udang yang merupakan suatu fungsi temperatur. Spesies pelagis lebih sering aktif daripada demersal dan memiliki nilai $\mathrm{K}$ yang tinggi (Mahasin, 2003).

Beverton dan Holt (1959) dalam Saputra (2009) beranggapan bahwa parameter kurvatur pertumbuhan (K) berkaitan dengan umur ikan, karena $\mathrm{K}$ menggambarkan waktu yang diperlukan untuk mencapai L $\infty$, dan umur yang panjang berkaitan dengan mortalitas. Secara umum, ikan yang memiliki nilai K yang tinggi mempunyai $\mathrm{M}$ yang besar, dan spesies dengan nilai K yang rendah mempunyai mortalitas yang rendah. Ikan yang tumbuh lambat (K rendah) akan cepat punah jika mortalitasnya tinggi.

Laju mortalitas

Mortalitas total (Z) pada penelitian ini didapatkan sebesar 1,6 per tahun dan mortalitas alaminya (M) sebesar 0,69 per tahun. Mortalitas akibat penangkapan ( $\mathrm{F}=\mathrm{Z}-\mathrm{M})$ dapat diduga sebesar 0,91 per tahun. Mortalitas penangkapan lebih tinggi daripada mortalitas alami, dapat diartikan bahwa kematian akibat penangkapan lebih tinggi daripada kematian pada habitatnya. Tingkat eksploitasi (E) didapatkan sebesar 0,57 per tahun. Tingkat eksploitasi tersebut lebih tinggi dari yang disarankan oleh Gulland (1971), yaitu eksploitasi dapat dikatakan optimal bila mortalitas alami dan mortalitas penangkapan seimbang sehingga $\mathrm{E}_{\mathrm{opt}}=0,5$. Tingkat eksploitasi yang sekarang terjadi dapat dikatakan rawan terhadap sumberdaya lobster di Perairan Cilacap, oleh karena itu perlu adanya pengelolaan dalam hal penangkapan dan apabila pengelolaan kurang efektif maka eksploitasi harus dipertahankan pada kondisi seperti sekarang.

Laju mortalitas merupakan kecepatan kematian yang dialami oleh lobster dalam kurun waktu tertentu. Sebab-sebab mortalitas pada suatu populasi antara lain karena kegiatan penangkapan (fishing), pemangsaan (predation), penyakit, dan ketuaan (Effendie, 1997; Sparre dan Venema 1999).

\section{Pola rekrutmen}

Berdasarkan hasil yang didapatkan bahwa rekrutmen lobster terjadi hampir setiap bulan. Pola penambahan baru lobster di Perairan Cilacap ini memiliki dua puncak yaitu pada bulan Juni dan Oktober. Penambahan lobster baru dipengaruhi oleh sifat lobster, dimana untuk lobster jenis $P$. homarus mampu memijah lebih dari satu kali dalam satu tahun (Chittleborough, 1974).

Penelitian yang dilakukan oleh Suman (1994) yang dilakukan di Perairan Pangandaran didapatkan bahwa puncak penambahan Lobster terjadi pada bulan Oktober (musim barat) dan bulan April (musim timur). Penelitian yang dilakukan oleh Jayakody (1993) di Sri Langka juga mendapatkan dua puncak penambahan baru lobster yaitu pada bulan April dan bulan September. Dari ketiga pernyataan tersebut terlihat bahwa puncak penambahan baru lobster dalam satu tahun terjadi dua kali, berlangsung antara bulan April - Mei dan September - Oktober.

\section{Kesimpulan}

Berdasarkan hasil penelitian yang telah dilakukan dapat diambil kesimpulan sebagai berikut:

1. Lobster jantan dan betina memiliki kemontokan yang relatif sama, dengan $\mathrm{Kn}=1,02$ pada jantan dan $\mathrm{Kn}=$ 1,01 pada betina;

2. Pertumbuhan lobster termasuk dalam kategori sedang hingga cepat, dengan $\mathrm{K}$ jantan $(0,31)$ dan $\mathrm{K}$ betina $(0,26)$;

3. Laju mortalitas tangkap (F) sebesar 0,91 per tahun sehingga lebih tinggi dari mortalitas alami (M) sebesar 0,69 per tahun; 
4. Tingkat eksploitasi yang didapatkan sebesar 0,57 per tahun sehingga melebihi optimum $\left(\mathrm{E}_{\mathrm{op}}=0,5\right)$ dan dapat dinyatakan dalam kondisi penangkapan berlebih (over-exploited). Pemanfaatan lobster di Perairan Cilacap termasuk dalam kategori growth-overfishing karena lobster yang ditangkap didominasi oleh ukuran yang masih kecil $\left(\mathrm{L}_{\mathrm{C} 50 \%}=43,5\right)$; dan

5. Puncak rekrutmen dari hasil pendugaan terjadi berkisar pada bulan Juni dan Oktober.

\section{Ucapan Terima Kasih}

Ucapan terima kasih ditujukan kepada Bapak Atmo dan Bapak Syueb yang telah membantu penulis selama kegiatan penelitian. Ucapan terima kasih ditujukan pula kepada Dr. Ir. Suradi Wijaya Saputra, MS dan Ir. Anhar Solichin, MSi atas bimbingannya dalam penyusunan penelitian ini.

\section{Daftar Pustaka}

Chan, T. Y. 1998. Shrimps and Prawns. Dalam : Carpenter KE, VH Niem. (Ed.). The Living Marine Resources of the Western Central Pacific. Vol. 2. Cephalopods, Crustaceans, Holothurians and Sharks. Food and Agriculture Organization of the United Nations Rome. Kanna, Iskandar. 2006. Lobster. Kanisius. Yogyakarta.

Chittleborough, R. G. 1974. Home Range, Homing, and Dominance in Juvenile Western Rock Lobster. Aust. J. Mar. Freshwat Res. 25, 227-234.

Dradjat, F. M. 2004. Bioekonomi Udang Karang (Panulirus spp.) pada Usaha Perikanan Tangkap Skala Kecil di Kabupaten Kebumen dan sekitarnya. [Tesis]. Program Pasca Sarjana. Universitas Diponegoro. Semarang

Effendie, M. I. 1997. Biologi Perikanan. Yayasan Pustaka Nusantara, Yogyakarta

Froese, R., M.L.D. Palomares and D. Pauly, 2000. Estimation of life history key facts of fishes. p. 167-175. In R. Froese and D. pauly (eds.) Fishbase 2000: concepts, designs \& data source. ICLARM, Manila, Philippines.

Jayakody, D. S. 1993. On The Growth, Mortality, and Recruitment of Spiny Lobster (Panulirus homarus) in Sri Lanka Waters. Naga The ICLARM Quarterly, Oct. 1993: 38-43

Mahasin, M. Z. 2003. Kajian Stok dan Bioekonomi Lobster (Panulirus spp.) untuk Menunjang Pemanfaatan Berkelanjutan di Propinsi Daerah Istimewa Yogyakarta. [Tesis]. Program Pasca Sarjana. Universitas Diponegoro. Semarang.

Morgan, G. R. 1980. Population Dynamics of Spiny Lobster. Dalam J.S. Cobb dan Bruce F. P. (eds), The Biology and Management of Lobster II, Academic Press, New York :189-217.

Saputra, W. S. 2008. Status Pemanfaatan Lobster (Panulirus sp) di Perairan Kebumen. Jurnal Saintek Perikanan Vol. 4, No. 2, $2009: 10-15$.

Saputra, W. S., S. Rudiyanti, dan A. Mahardhini. 2008. Evaluasi Tingkat Eksploitasi Sumberdaya Ikan Gulamah (Johnius sp) berdasarkan Data TPI PPS Cilacap. Jurnal Saintek Perikanan Vol. 4, No. 1, 2008 : 56 61.

Saputra, W. S. 2009. Dinamika Populasi Berbasis Riset. Badan Penerbit Universitas Diponegoro Semarang. Semarang.

Spare, P. dan S. C. Venema. 1999. Introduksi Pengkajian Stok Ikan Tropis: Buku I Manual. Kerjasama PBB, Pusat Penelitian dan Pengembangan Perikanan dan Badan Penelitian dan Pengembangan Pertanian, Jakarta.

Subani, W., B. Sadhotomo dan K. Suwirya. 1983. Penelitian tentang Pertumbuhan dan Beberapa Parameter Biologi Udang Patung (Panulirus homarus) di Perairan Pantai Selatan Bali. Laporan Penelitian Perikanan Laut No. 24: 57-65

Sudrajad, A. dan D. Nugroho. 1983. Penelitian Pendahuluan Beberapa Aspek Biologi Ikan Selar (Selaroides leptolepis) di Perairan Paparan Sunda. Laporan Penelitian Perikanan Laut No. $29: 79$ - 88.

Suman, A., W. Subani dan P. Prahoro. 1994. Beberapa Parameter Biologi Udang Patung (Panulirus homarus) Di Perairan Pangandaran Jawa Barat. Jurnal Penelitian Perikanan Laut. Balai Peneltian Perikanan Laut. Jakarta 